\title{
Socio-Demographic Pattern of Patients Suffering from Extra Pulmonary Tuberculosis
}

\author{
Dr. Imtiaz Ahmed ${ }^{1 *}$, Dr. Sadia Sabah ${ }^{2}$, Dr. Mohammad Abdus Sattar Sarker ${ }^{3}$, Dr. Mohammed Mostanshir Billah ${ }^{4}$, Dr.
} Md. Tariq $\operatorname{Hasan}^{5}$, Dr. ABM Abdullah ${ }^{6}$

\author{
${ }^{1}$ Assistant Professor, Dept of Medicine, Sir Salimullah Medical College \& Mitford Hospital, Dhaka, Bangladesh \\ ${ }^{2}$ Medical Officer, Dept. of Internal Medicine, Bangabandhu Sheikh Mujib Medical University Hospital, Dhaka, Bangladesh \\ ${ }^{3}$ Associate professor, Dept. of Medicine, Sir Salimullah Medical College and Mitford Hospital, Dhaka, Bangladesh \\ ${ }^{4}$ Medical Officer, OSD, DGHS, Mohakhali, Dhaka,Bangladesh. \\ ${ }^{5}$ MD Resident, Phase-B, Dept. of Oncology, Bangabandhu Sheikh Mujib Medical University Hospital, Dhaka, Bangladesh \\ ${ }^{6}$ Professor, UGC, Bangabandhu Sheikh Mujib Medical University Hospital, Dhaka, Bangladesh
}

DOI: $10.36347 /$ sjams.2020.v08i07.017

| Received: 21.06 .2020 | Accepted: 29.06.2020 | Published: 20.07.2020

*Corresponding author: Dr. Imtiaz Ahmed

Abstract

Original Research Article

Objective: In this study our main goal is to evaluate the demographic pattern of patients suffering from extra pulmonary tuberculosis. Method: This cross-sectional descriptive type study was carried out at Medicine departments of Sir Salimullah Medical College \& Mitford Hospital, Dhaka from $19^{\text {th }}$ December 2016 to $18^{\text {th }}$ June 2017 . A total 100 patients were included in the study where detailed history was taken then thorough clinical examinations. Results: More than fifty percent $(56.0 \%)$ of the patients were in the age group 20-40 years and 30.0\% of the patients were in age group 20 and below while only $14.0 \%$ of the patients were in the age group above 40 years. Also, male and female ratio of the patients was almost equal. Majority of the patient's had the history of contact with TB patients. Majority of the patient's had normal chest X-ray findings $(60.0 \%)$ while $26.0 \%$ of the patient's had homogenous opacity in chest $\mathrm{X}$ ray findings and $2.0 \%$ and $4.0 \%$ of the patient's had cavity lesion and fibrosis respectively, in chest $\mathrm{x}$-ray findings. Conclusion: Our study concludes that majority of the tuberculosis patients are within the economically productive age group ranged between 20-40 years. Females are the majority of the patients with extra pulmonary tuberculosis. Based on this results TB control programme might usefully target young and female populations for early diagnosis to decrease tuberculosis morbidity and mortality.

Keywords: Demographic pattern, tuberculosis (TB), extra pulmonary tuberculosis.

Copyright @ 2020: This is an open-access article distributed under the terms of the Creative Commons Attribution license which permits unrestricted use, distribution, and reproduction in any medium for non-commercial use (NonCommercial, or CC-BY-NC) provided the original author and source are credited.

\section{INTRODUCTION}

Tuberculosis is a common disease throughout the world, especially in developing countries. Millions of people have died from tuberculosis (TB), a leading chronic infectious killer of all age groups and the second most common infectious disease worldwide. It is an infection with human strains of Mycobacterium tuberculosis with the occurrence of the characteristic immune response. ${ }^{1-2}$ The most common form of the disease, which is essential for the spread of TB, is pulmonary tuberculosis (PTB). Tuberculosis can affect any organ in the body. The Extra-pulmonary tuberculosis (EPTB) is referred to isolated TB at any site in the body outside the lungs.

Bangladesh is a country with high tuberculosis burden. As a low middle-income country, facilities for diagnosis of extra-pulmonary tuberculosis i.e. detection of M. Tuberculosis by microbiological, culture and histopathological methods is only available in advanced hospital that lacks in number. In this study our main goal is to evaluate the demographic pattern of patients suffering from extra pulmonary tuberculosis.

\section{OBJECTIVE}

General objective

- To assess the demographic pattern of patients suffering from extra pulmonary tuberculosis.

Specific objective

- To detect nutritional status of patients.

- To evaluate the Chest x-ray findings of patients.

\section{MethOdOLOGY \\ Study type}

- This was a cross-sectional descriptive type study. 
Place of the study and period of the study

- The study was carried out at Medicine departments of Sir Salimullah Medical College $\&$ Mitford Hospital, Dhaka from $19^{\text {th }}$ December 2016 to $18^{\text {th }}$ June 2017.

\section{Study population and sample size}

- A total 100 patients included in the study, from Medicine departments of Sir Salimullah Medical College \& Mitford Hospital, hospitalized for investigation for pyrexia of unknown origin and clinically suspected TB patients. Adenosine deaminase level was measured during diagnosis of PUO.

\section{Sampling method}

- Sample of the study was selected by purposive method.

\section{Inclusion criteria}

- Patients age more than 12 years.

- Patients with pyrexia of unknown origin (PUO) whom were suspected for extrapulmonary tuberculosis.

- Diagnosed case of extra-pulmonary tuberculosis.

- Given informed written consent.

\section{Procedure of data collection}

- Detailed history was taken then thorough clinical examinations were done. In all patient serum ADA, tuberculin skin test and other test on the basis of site of involvement such as for pulmonary sputum for AFB, CXR, Histopathological examination (FNAC/Biopsy), X-ray Spine, Bone, Joints, Cytological examination of effusions, ascitis, CSF, CT scan/MRI of brain (with contrast if needed), molecular test e.g. Gene Xpert was done. All these data were collected by using preformed data sheet.

\section{DATA ANALYSIS}

Data entry, quality control and data cleaning had been done following standard method. All data forms and questionnaires had been checked for errors and necessary correction had been made before data entry. Data had been entered using data entry program with built in range and consistency checks (SPSS). The prevalence rate had been determined by simple percentages. Chi-square test was used to assess comparison between different groups. A p-value $<0.05$ was considered statistically significant.

\section{RESULTS}

In table-1 shows distribution of the patients according to age and gender where more than fifty percent $(56.0 \%)$ of the patients were in the age group $20-40$ years and $30.0 \%$ of the patients were in age group 20 and below while only $14.0 \%$ of the patients were in the age group above 40 years. Also, male and female ratio of the patients was almost equal. The following table is given below in detail:

Table-1: Distribution of the patients according to age and gender

\begin{tabular}{|l|c|}
\hline Age group, years & $\%$ \\
\hline 20 and below & $30 \%$ \\
\hline 20-40 years & $56 \%$ \\
\hline above 40 years & $14 \%$ \\
\hline Gender & $\%$ \\
\hline Male & $48 \%$ \\
\hline Female & $52 \%$ \\
\hline
\end{tabular}

In table-2 shows distribution of respondents by occupation. More than one fourth of the respondents were housewife $(28.0 \%)$ and $24.0 \%$ of the respondents were students and day laborer while $14.0 \%$ of the respondents were employee. The following table is given below in detail:

Table-2: Distribution of respondents by occupation

\begin{tabular}{|l|l|l|}
\hline Occupation & Number & Percentage \\
\hline Housewife & 28 & $28 \%$ \\
\hline Students & 24 & $24 \%$ \\
\hline Day laborer & 24 & $24 \%$ \\
\hline Employee & 14 & $14 \%$ \\
\hline Businessman & 6 & $6 \%$ \\
\hline Unemployed & 2 & $2 \%$ \\
\hline Retired & 2 & $2 \%$ \\
\hline
\end{tabular}

In figure-1 shows distribution of respondents by residence. Half of the respondents resided in the urban area and half were in the rural. The following figure is given below in detail:

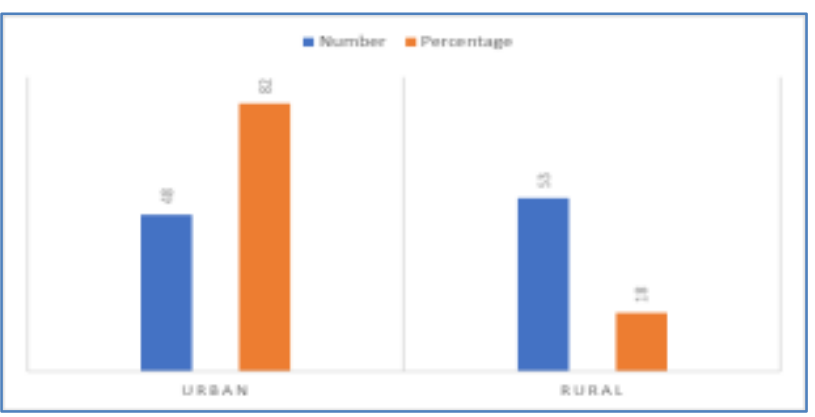

Fig-1: Distribution of respondents by residence 
In table-3 shows distribution of respondents by smoking history and alcohol consumption. About three fifths of the patients had history of smoking. One tenth of the patients had the history of alcohol consumption. The following table is given below in detail:

Table-3: Distribution of respondents by smoking history and alcohol consumption

\begin{tabular}{|l|l|l|}
\hline Smoking history & Number & Percentage \\
\hline Yes & 38 & 38.0 \\
\hline No & 62 & 62.0 \\
\hline Alcohol consumption & Number & Percentage \\
\hline Yes & 12 & 12.0 \\
\hline No & 88 & 88.0 \\
\hline
\end{tabular}

In table-4 shows distribution of respondents by nutritional status. Majority of the patient's nutritional status were average and $28.0 \%$ of the patient's nutritional status were poor. The following table is given below in detail:

Table-4: Distribution of respondents by nutritional status

\begin{tabular}{|l|l|l|}
\hline Nutritional status & Number & Percentage \\
\hline Poor & 28 & 28.0 \\
\hline Average & 60 & 60.0 \\
\hline Good & 12 & 12.0 \\
\hline Total & 100 & 100.0 \\
\hline
\end{tabular}

In figure-2 shows distribution of respondents by Socio-economic condition. Two fifths of the patient's socio-economic conditions were middle class while $46.0 \%$ of the patient's socio-economic conditions were poor and very few were lower middle class. The following figure is given below in detail:

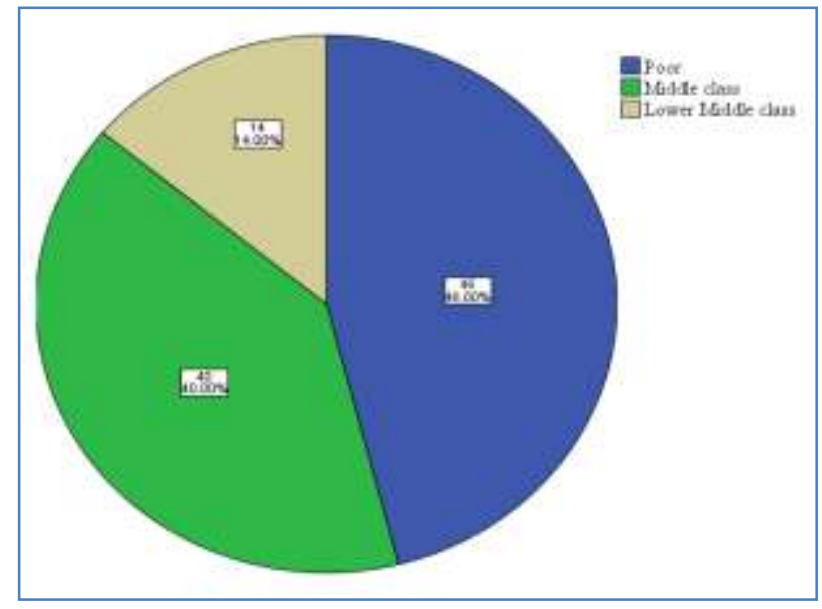

Fig-2: Distribution of respondents by socio-economic condition

In figure-3 shows distribution of respondents by history of contact with TB patients. Majority of the patient's had the history of contact with TB patients. The following figure is given below in detail:

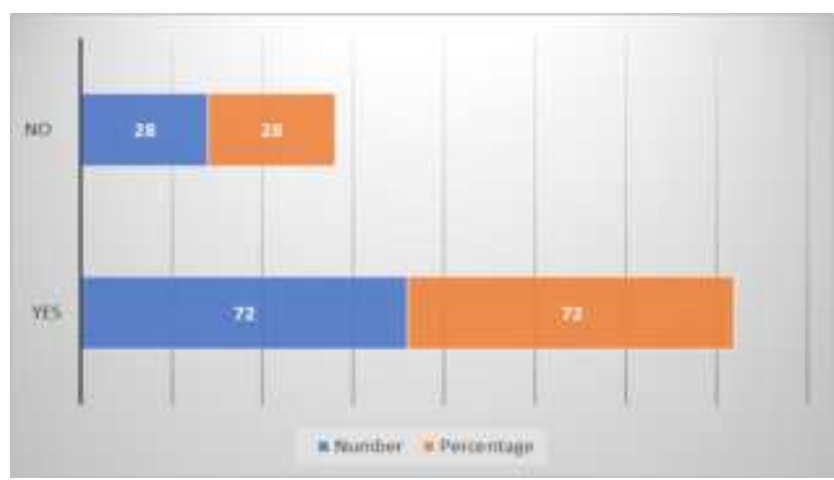

Fig-3: Distribution of respondent by of contact with TB patients 
In table- 5 shows distribution of respondents by routine blood analysis where WBC average in respondents was $13210.2 \pm 3590.4$, Neutrophil average count was $55.7 \pm 12.7$ and Platelet count average was $282300 \pm 104468$. The following table is given below in detail:

Table-5: Distribution of respondents by routine blood analysis

\begin{tabular}{|l|l|l|l|}
\hline Routine blood analysis & Number & Range & Average \\
\hline Hb percentage & 100 & $8.0-15.0$ & $9.92 \pm 1.27$ \\
\hline ESR & 100 & 13 & $86.4 \pm 22.1$ \\
\hline Total count of WBC & 100 & $5500-25000$ & $13210.2 \pm 3590.4$ \\
\hline Neutrophil count & 100 & $30-75$ & $55.7 \pm 12.7$ \\
\hline Lymphocyte count & 100 & $18-65$ & $39.4 \pm 12.7$ \\
\hline Monocyte count & 100 & $0-5$ & $1.9 \pm 1.5$ \\
\hline Basophil count & 100 & $0-1$ & $0.02 \pm 0.14$ \\
\hline Eosinophil count & 100 & $0-8$ & $2.9 \pm 1.8$ \\
\hline Platelet count & 100 & $150000-60000$ & $282300 \pm 104468$ \\
\hline
\end{tabular}

In table- 6 shows distribution of respondents by Chest x-ray. Majority of the patient's had normal chest X-ray findings $(60.0 \%)$ while $26.0 \%$ of the patient's had homogenous opacity in chest x-ray findings and $2.0 \%$ and $4.0 \%$ of the patient's had cavity lesion and fibrosis respectively, in chest $x$-ray findings. The following table is given below in detail:

Table-6: Distribution of respondent by Chest x-ray findings
\begin{tabular}{|l|l|l|}
\hline Chest x-ray findings & Number & Percentage \\
\hline Normal & 60 & 60.0 \\
\hline Homogenous Opacity & 26 & 26.0 \\
\hline Others & 8 & 8.0 \\
\hline Fibrosis & 4 & 4.0 \\
\hline Cavity lesion & 2 & 2.0 \\
\hline
\end{tabular}

In figure- 4 shows distribution of respondent by Tuberculin test where majority of the patients had positive tuberculin test $(56.0 \%)$. The following figure is given below in detail:

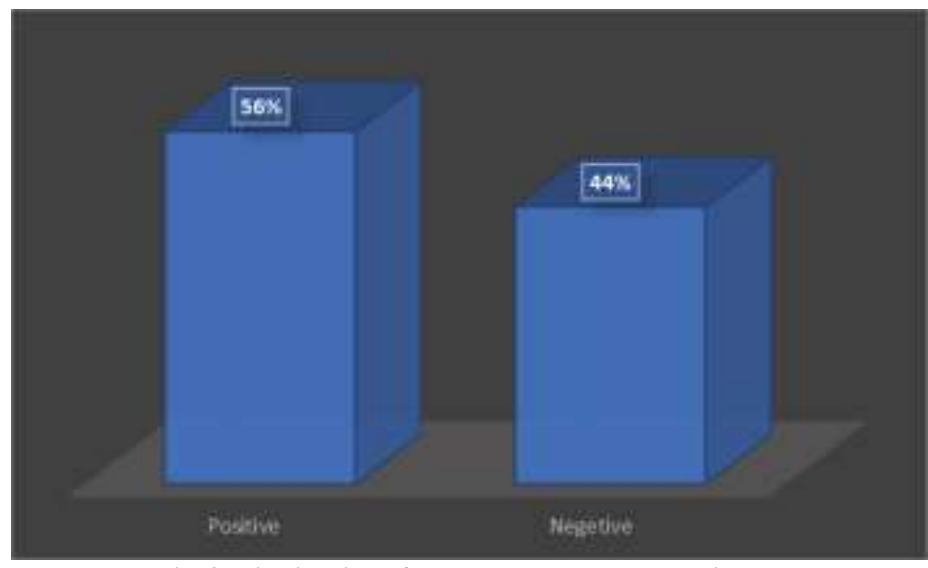

Fig-4: Distribution of respondents by Tuberculin test

\section{DISCUSSION}

More than fifty percent of the patients were in the age group 20-40 years and the mean (SD) age was $31.4 \pm 15.2$ years and Male and female ratio of the patients was almost equal. In another study similar result was found where the mean (SD) age was $29.2 \pm$ 12.2 years [3]. This result was agreed with other report which was found that the mean age of tuberculous group was $33.9 \pm 13.2$ years that of malignant group was $45.5 \pm 16.8$ years [4].
A total of 300 pleural fluid samples were submitted to the laboratory for the diagnosis of TB over the 3-year study period of which 237 with available ADA results were included in one study. There were 197 tubercular pleural effusion patients: mean age 35 years with 107 females. Dissimilarities was found in a study with exudative pleural effusion where the study population included 164 males and 62 females, with a mean age of 48[5]. 
Majority of the patients had positive tuberculin test $(57.1 \%)$ and we found similar findings in other studies where tuberculin skin tests were positive in $32 / 36$ tuberculous pericarditis patients (89\% 'true positive ') and $7 / 16$ patients with non-tuberculous effusions[6].

\section{Conclusion}

Our study concludes that majority of the tuberculosis patients are within the economically productive age group ranged between 20-40 years. Females are the majority of the patients with extra pulmonary tuberculosis. Based on this results TB control programme might usefully target young and female populations for early diagnosis to decrease tuberculosis morbidity and mortality.

\section{REFERENCES}

1. World Health Organization. Global tuberculosis control: surveillance, planning, finances. Geneva: WHO,

2008. http://whqlibdoc.who.int/publications/2008/978924

1563543_eng.pdf - accessible 6 January 2012.

2. Nelson LJ, Wells CD. Global epidemiology of childhood tuberculosis. Int $\mathrm{J}$ Tuberc Lung Dis. 2004; 8(5): 636-47.

3. Helmy NA, Eissa SA, Masoud HH, Elessawy AF, Ahmed RI. Diagnostic value of adenosine deaminase in tuberculous and malignant pleural effusion Egyptian Journal of Chest Diseases and Tuberculosis.2012; 61, 413-417

4. Valdes L, Pose A, San Jose E, Martinez Vazquez JM. Tuberculous pleural effusions. Eur J Intern Med. 2003 Mar; 14(2): 77-88.

5. Baba K, Hoosen AA, Langeland N, Dyrhol-Riise AM. Adenosine deaminase activity is a sensitive marker for the diagnosis of tuberculous pleuritis in patients with very low CD4 counts. PLoS One. 2008; 3:e2788.

6. Reuter H, Burgess L, Vuuren WV and Doubell A. Diagnosing tuberculous pericarditis Q J Med. 2006; 99:827-839. 